\title{
Estimation of nutrient export in eucalypts genotypes under different harvest intensities in southern Brazil
}

\author{
Estimación de la exportación de nutrientes en genotipos de eucalipto \\ bajo diferentes intensidades de cosecha en el sur de Brasil
}

\author{
Kristiana Fiorentin dos Santos ${ }^{1,4 *}$, Aline Aparecida Ludvichak1, Túlio Baroso Queiroz², \\ Mauro Valdir Schumacher ${ }^{1}$, Elias Frank de Araújo ${ }^{3}$, Dione Richer Momolliabstract ${ }^{1}$
}

\begin{abstract}
The study of the nutrients removed with forest harvesting is presented as an essential fator favoring the sustainable use of forest stands. The research was carried out in an experimental area in Horto Florestal Terra Dura in the municipality of Eldorado do Sul, RS, Brazil, where six Eucalyptus clones were planted. Based on the nutrient stock of each biomass component, the simulation of nutrient removal through biomass harvesting was calculated for three scenarios: (1) harvesting of stemwood, (2) harvesting of stemwood with stembark, and (3) harvesting of all aboveground biomass. In the first scenario, the highest amount of nutrients exported with biomass harvest occurred in the Eucalyptus hybrids E. urophylla $\times$ E. globulus $(\mathrm{N}, \mathrm{K}, \mathrm{S}$, and $\mathrm{Fe})$ and E. urophylla $\times$ E. grandis $(\mathrm{Ca}, \mathrm{B}, \mathrm{Cu}$, and $\mathrm{Zn}$ ). In the second scenario, the highest nutrient exportation occurred in E. benthamii (Provenance 1) (N, P, Ca, $\mathrm{Mn}$, and $\mathrm{B}$ ) and hybrid E. urophylla $\mathrm{x}$ E. globulus (K, S, and $\mathrm{Fe})$. In the third scenario, the highest nutrient exportation occurred in E. benthamii (Provenance 1) ( $\mathrm{P}, \mathrm{Ca}, \mathrm{B}, \mathrm{Mn}$, and $\mathrm{Zn})$, E. grandis $(\mathrm{Mg}$ and $\mathrm{Cu})$, and hybrid E. urophylla $\mathrm{x}$ E. globulus $(\mathrm{N}, \mathrm{K}, \mathrm{S}$, and $\mathrm{Fe})$. Harvesting of all aboveground biomass was the most aggressive scenario, showing the highest export of nutrients. However, for reducing the nutritional impact of biomass harvesting, the best scenario was the one in which only stemwood was harvested.
\end{abstract}

Keywords: Nutrient removal, Eucalyptus clones, Forest harvest.

\section{RESUMEN}

El estudio de los nutrientes extraídos con la cosecha forestal se presenta como un factor esencial que favorece el uso sostenible de las plantaciones forestales. La investigación se llevó a cabo en un área experimental en Horto Florestal Terra Dura en el municipio de Eldorado do Sul, RS, Brasil, donde se plantaron seis clones de eucalipto. Con base en el contenido de nutrientes de cada componente de biomasa, la simulación de la extracción de nutrientes por la recolección de biomasa se calculó para tres tratamientos: (1) cosecha de madera de tallo; (2) cosecha de madera con corteza de tallo; y (3) cosecha de toda la biomasa aérea. En el primer tratamiento, la mayor cantidad de nutrientes exportados con la cosecha de biomasa ocurrió en los híbridos de eucalipto E. urophylla x E. globulus $(N, K, S$ y $F e)$ y E. urophylla x E. grandis $(C a, B, C u$ y $\mathrm{Zn})$. En el segundo tratamiento, la mayor exportación de nutrientes se produjo en $\mathrm{E}$. benthamii (Procedencia 1) ( $N, P, C a, M n$ y B) y E. urophylla x E. globulus híbridos $(K, S$ y $\mathrm{Fe})$. En el tercer tratamiento, la mayor exportación de nutrientes ocurrió en E. benthamii (Procedencia 1$)(P, C a$, $B, M n$ y $\mathrm{Zn}$ ), E. grandis $(\mathrm{Mg}$ y $\mathrm{Cu}$ ) y E. urophylla x E. globulus híbridos $(N, K, S$ y $\mathrm{Fe}$ ). La recolección de toda la biomasa aérea fue el escenario más agresivo, mostrando la mayor exportación de nutrientes. Sin embargo, para reducir el impacto nutricional de la recolección de biomasa, el mejor tratamiento fue aquel en el que solo se cosechaba madera de tallo.

Palabras clave: eliminación de nutrientes, clones de eucalipto, cosecha forestal.

\section{Introduction}

Among the numerous existing tree genera, the genus Eucalyptus, owing to its characteristics of fast growth, high productivity, wide species diversity, great adaptability to different climate and soil conditions, and varied applications, has gained considerable economic significance worldwide (Mora and Garcia 2000).

1 Federal University of Santa Maria, Department of Forest Engineering. Santa Maria, Rio Grande do Sul, Brazil.

2 State University of São Paulo "Júlio de Mesquita Filho" - UNESP, Department of Forest Engineering. Botucatu, São Paulo, Brazil.

3 Celulose Riograndense. Guaíba, Rio Grande do Sul, Brazil.

4 Universidad Regional de Blumenau. Blumenau, Santa Catarina, Brasil.

* Corresponding author: kristianafiorentin@gmail.com

Fecha de Recepción: 6 de Agosto, 2019.

Fecha de Aceptación: 28 de Diciembre, 2019. 
Most eucalypts plantations, besides presenting high productivity, are managed in short rotations (6-8 years) (Gonçalves et al., 2013), when compared with native forest species (Silva et al., 1983). However, the rapid growth of planted forests in the country imposes a high demand on soil resources, mainly water and nutrients, raising questions about the support capacity and sustainability of these systems when used intensively (Bellote et al., 2008).

In order to define management practices, both in forest stands and natural forests, the study of nutrients removed with forest harvesting is an essential factor favoring the sustainable use of these systems. Considering that the amount of nutrients exported from a stand by forest harvesting is determined by the proportions between the biomass components and the harvest intensity used. In this context, the maintenance of forest productivity will depend on the proportion between the nutrients that are exported and those that remain in the system, in organic and mineral forms (Viera et al., 2015). To do this, prolonging the harvest cycle and adopting a harvest regime of only stemwood are important ways to reduce the export of nutrients (Wang et al., 2016).

The quantification of biomass and the export of nutrients in forest stands is of fundamental importance to understand the dynamics of nutrients in various compartments of the stands, thus allowing the identification of the indicators of possible effects of some silvicultural techniques (Londero et al., 2011). Therefore, the knowledge of nutrient allocation in different parts of trees allows a forester to select the harvesting techniques that reduce the exportation of nutrients from the site of harvest (Santana et al., 2008). In view of the above information, the present work aimed to estimate the amount of nutrients exported in Eucalyptus genotypes exposed to different harvest intensities in southern Brazil.

\section{Materials And Methods}

\section{Study site}

The present study was carried out in an experimental area in Horto Florestal Terra Dura owned by Celulose Riograndense - CMPC, in the municipality of Eldorado do Sul, RS, Brazil. This study area is located at the geographic coordinates of $30^{\circ} 11^{\prime} 30.3^{\prime \prime} S$ and $51^{\circ} 37^{\prime} 47.7^{\prime \prime} \mathrm{W}$, with an altitude of approximately $158 \mathrm{~m}$.

According to the climatic classification of Köppen, the predominant climate of the study area is Cfa (humid subtropical climate), with an average temperature of $19^{\circ} \mathrm{C}$ and an average annual precipitation of 1,400 $\mathrm{mm}$ (Alvares et al. 2013).

The soil of the experimental area is of the RedYellow Argissol type. The Argisols comprise the soils made up of a mineral material charecterized by the presence of the textural B-horizon of low- or high-activity clay with low base saturation or allitic character (EMBRAPA, 2009). Table 1 shows the chemical attributes of the soil at a depth of 0 to $130 \mathrm{~cm}$.

Table 1. Chemical atributes of the soil of the area implanted with different genotypes of Eucalyptus.

\begin{tabular}{|c|c|c|c|c|c|c|c|c|}
\hline Depht & $\mathrm{N}$ & $\mathrm{P}$ & $\mathrm{K}$ & $\mathrm{Ca}$ & $\mathrm{Mg}$ & $\mathrm{S}$ & B & $\mathrm{Zn}$ \\
\hline$(\mathrm{cm})$ & $\%$ & $\mathrm{mg} \mathrm{g}^{-1}$ & \multicolumn{3}{|c|}{$\mathrm{cmol}_{\mathrm{c}} \mathrm{dm}^{-3}$} & $\mathrm{mg} \mathrm{dm}^{-3}$ & \multicolumn{2}{|c|}{$\mathrm{mg} \mathrm{dm}-3$} \\
\hline $0-30$ & 0.10 & 2.00 & 0.14 & 3.25 & 0.85 & 19.35 & 0.40 & 0.50 \\
\hline $30-60$ & 0.09 & 1.60 & 0.14 & 0.85 & 0.50 & 32.50 & 0.65 & 0.50 \\
\hline $60-90$ & 0.08 & 0.95 & 0.15 & 1.00 & 0.80 & 61.70 & 0.50 & 0.25 \\
\hline $90-100$ & 0.06 & 0.65 & 0.14 & 0.95 & 0.90 & 60.90 & 0.30 & 0.30 \\
\hline $100-130$ & 0.04 & 0.60 & 0.12 & 0.90 & 0.90 & 59.00 & 0.30 & 0.30 \\
\hline Depht & $\mathrm{Mn}$ & $\mathrm{Cu}$ & $\mathrm{Fe}$ & $\mathrm{pH}$ & O.C & V & $\mathrm{m}$ & $\mathrm{T}$ \\
\hline$(\mathrm{cm})$ & \multicolumn{2}{|c|}{$\mathrm{mg} \mathrm{dm} \mathrm{dm}^{-3}$} & $\mathrm{~g} \mathrm{dm}^{3}$ & $\overline{\mathrm{H}_{2} \mathrm{O}}$ & & $\%$ & & $\mathrm{cmol}_{\mathrm{c}} \mathrm{dm}^{-3}$ \\
\hline $0-30$ & 12.50 & 0.75 & 0.10 & 5.00 & 0.88 & 35.00 & 34.00 & 10.30 \\
\hline $30-60$ & 13.00 & 1.20 & 0.10 & 4.25 & 0.77 & 11.00 & 71.00 & 13.95 \\
\hline $60-90$ & 6.50 & 1.15 & 0.10 & 4.40 & 0.66 & 14.50 & 68.50 & 15.25 \\
\hline $90-100$ & 4.50 & 0.95 & 0.10 & 4.60 & 0.42 & 17.00 & 63.50 & 11.95 \\
\hline $100-130$ & 4.50 & 0.65 & 0.10 & 4.65 & 0.22 & 19.50 & 60.50 & 10.00 \\
\hline
\end{tabular}

O.C: organic carbon; V: base saturation; $\mathrm{m}=$ saturation by aluminum; t: Effective cation exchange capacity. 


\section{Plantation of forest stands}

In April 2012, in a spacing of $3 \mathrm{~m} \mathrm{x} 3 \mathrm{~m}$, six clones of the genus Eucalyptus were planted: E. benthamii (P1); E. benthamii ( $\mathrm{P} 2) ;$ E. saligna; E. dunnii; hybrid of E. urophylla $\mathrm{x}$ E. globulus (E. uroglobulus) and hybrid of E. urophylla $\mathrm{x}$ E. grandis (E. urograndis). E. benthamii $(\mathrm{P} 1)$ is a provenance originating from Guarapuava, Paraná, Brazil and E. benthamii (P2) is from Telemaco Borba, Paraná, Brazil.

Subsoiling was performed at a depth of $60 \mathrm{~cm}$, using a subsoiler with three stems. Subsequently, a liming treatment was performed using $2 \mathrm{Mg} \mathrm{ha}^{-1}$ of limestone and $200 \mathrm{~kg} \mathrm{ha}^{-1}$ of single superphosphate. As plantation fertilizers, 110 g plant $^{-1}$ of $\mathrm{N}^{-} \mathrm{P}_{2} \mathrm{O}_{5}-\mathrm{K}_{2} \mathrm{O}$ $(06: 30: 06)+0.3 \% \mathrm{Zn}$ and $0.2 \% \mathrm{Cu}$ were applied. For coverage fertilization, $200 \mathrm{~kg} \mathrm{ha}^{-1}$ of $\mathrm{N}-\mathrm{P}_{2} \mathrm{O}_{5}-\mathrm{K}_{2} \mathrm{O}$ $(12: 00: 20)+0.7 \% \mathrm{~B}$ was applied, and for maintenance fertilization, $300 \mathrm{~kg} \mathrm{ha}^{-1}$ of $\mathrm{N}-\mathrm{P}_{2} \mathrm{O}_{5}-\mathrm{K}_{2} \mathrm{O}$ (24:00:26) $+0.5 \% \mathrm{~B}$ was applied. At the time of data collection, the stands were 49 months old.

\section{Biomass and nutrients}

From the dendrometric information collected, three trees of medium diameter were sampled for each genotype. The selected trees were felled and separated in to following components: leaves, branches, stembark, and stemwood. The amounts of the nutrients in the Eucalyptus components were obtained by multiplying the dried biomass with the mean nutrient concentration (Table 2).

\section{Estimation of nutrient removal by harvest}

Simulation of nutrient removal through biomass harvesting was performed for three scenarios based on the nutrient stock of each biomass component:

- Harvest of the stemwood;

- Harvesting the stemwood with stembark;

- Harvesting of all aboveground biomass.

\section{Results and Discussion}

\section{Exportation of nutrients by biomass harvesting}

Harvesting of all aboveground biomass was the most aggressive nutrient export scenario (Table 3).
In contrast, the harvesting only the stemwood showed the lowest nutrient removal from the system, regardless of the genotype. This scenario maintained the macro and micronutrients accumulated in the other biomass components, which varied from 54 to $79 \%$ of $\mathrm{N}$ (E. urograndis and E. benthamii (P2)); 52 to $63 \%$ of $\mathrm{P}(E$. benthamii (P1) and E. saligna); 36 to $46 \%$ of $\mathrm{K}$ (E. urograndis and E. dunnii); 71 to $82 \%$ of $\mathrm{Ca}($ E. dunnii and E. benthamii $(\mathrm{P} 1)) ; 56$ to $75 \%$ of $\mathrm{Mg}($ E. dunnii and E. benthamii (P2)); 33 to $45 \%$ of $\mathrm{S}$ (E. uroglobulus and E. benthamii (P1)); 43 to $66 \%$ of B (E. urograndis and E. uroglobulus); 39 to $53 \%$ of $\mathrm{Cu}$ (E. urograndis and E. dunnii); 14 to $36 \%$ of $\mathrm{Fe}$ (E. uroglobulus and E. benthamii (P2)); 77 to $87 \%$ of $\mathrm{Mn}$ (E. dunnii and E. saligna); and 28 to $47 \%$ of $\mathrm{Zn}$ (E. urograndis and E. dunnii).

In a forest, the organic blanket and farm waste constitute the main form of transfer or return of mineral elements from the vegetation to the soil. Thus, the maintenance of forest productivity depends on the proportion between the nutrients that are exported and those that remain in the system, in organic and mineral forms (Drumond et al. 1997).

Considering the harvest of the wood with the stembark, the permanence of the nutrients in the area reduces to 44 to $55 \%$ of $\mathrm{N}$ (E. urograndis and E. uroglobulus); 29 to $43 \%$ of $\mathrm{P}$ (E. benthamii (P2) and E. uroglobulus); 19 to $26 \%$ of $\mathrm{K}$ (E. benthamii (P2) and E. saligna); 26 to $37 \%$ of $\mathrm{Ca}$ (E. benthamii (P2) and E. uroglobulus); 26 to $36 \%$ of $\mathrm{Mg}$ (E. benthamii (P2) and E. uroglobulus); 25 to $34 \%$ of S (E. saligna and E. benthamii (P1)); 28 to $40 \%$ of B (E. dunnii and E. uroglobulus); 27 to $37 \%$ of $\mathrm{Cu}$ (E. urograndis and E. dunnii); 11 to $27 \%$ of $\mathrm{Fe}$ (E. uroglobulus and E. benthamii (P2)); 33 to $46 \%$ of Mn (E. saligna and E. uroglobulus); and 17 to $28 \%$ of $\mathrm{Zn}$ (E. benthamii (P2) and E. dunnii).

According to Bellote and Silva (2004), the biomass of the bark is significantly smaller than that of the wood; however, it presents itself as an important nutrient storage site, especially of Ca. In this context, it becomes more sustainable to harvest only stemwood. According to Merino et al. (2005), the current practices of harvesting (stem and bark removal) result in high export rates of $\mathrm{P}, \mathrm{K}, \mathrm{Ca}$, and $\mathrm{Mg}$, especially in Eucalyptus plantations, because of the high productivity and low nutrient efficiency of the species of this genus.

In relation to macronutrients, it has been observed that with the exception of the third scenario (stem and canopy) in the stand of E. dunnii, where 
Table 2. Amount of nutrients in the biomass components of different genotypes of Eucalyptus at 49-month-old established in Eldorado do Sul, RS, Brazil.

\begin{tabular}{|c|c|c|c|c|c|c|c|c|c|c|c|c|}
\hline \multirow{2}{*}{ Genotype } & \multirow{2}{*}{ Component } & $\mathrm{N}$ & $\mathrm{P}$ & $\mathrm{K}$ & $\mathrm{Ca}$ & $\mathrm{Mg}$ & $\mathrm{S}$ & B & $\mathrm{Cu}$ & $\mathrm{Fe}$ & $\mathrm{Mn}$ & $\mathrm{Zn}$ \\
\hline & & \multicolumn{6}{|c|}{$\mathrm{kg} \mathrm{ha}^{-1}$} & \multicolumn{5}{|c|}{$\mathrm{g} \mathrm{ha}^{-1}$} \\
\hline \multirow{5}{*}{ E. benthamii $(\mathrm{P} 1)$} & Leaves & 99.70 & 6.00 & 36.00 & 26.50 & 12.40 & 5.90 & 86.00 & 21.40 & 586.30 & $2,033.50$ & 70.40 \\
\hline & Branches & 13.40 & 2.40 & 23.50 & 39.30 & 12.80 & 2.20 & 43.60 & 26.30 & 362.90 & $2,173.40$ & 76.20 \\
\hline & Stembark & 44.10 & 4.80 & 48.60 & 129.80 & 30.20 & 2.70 & 115.30 & 26.10 & 265.20 & $4,164.70$ & 130.70 \\
\hline & Stemwood & 65.50 & 12.30 & 143.50 & 41.90 & 20.10 & 13.20 & 210.30 & 78.30 & $4,956.10$ & $1,515.90$ & 360.90 \\
\hline & Total & 222.70 & 25.60 & 251.60 & 237.60 & 75.50 & 24.00 & 455.20 & 152.20 & $6,170.60$ & $9,887.50$ & 638.20 \\
\hline \multirow{5}{*}{ E. benthamii $(\mathrm{P} 2)$} & Leaves & 92.50 & 5.00 & 26.00 & 20.20 & 10.70 & 5.00 & 95.60 & 22.40 & 490.40 & 1.400 .70 & 51.30 \\
\hline & Branches & 7.70 & 1.30 & 14.60 & 14.90 & 6.70 & 1.50 & 26.40 & 14.20 & 228.60 & 835.00 & 47.00 \\
\hline & Stembark & 45.60 & 6.00 & 42.30 & 70.40 & 31.80 & 3.00 & 113.20 & 21.90 & 240.50 & 2.452 .30 & 113.30 \\
\hline & Stemwood & 37.90 & 9.60 & 127.60 & 31.40 & 16.70 & 15.50 & 155.20 & 61.40 & $1,688.90$ & $1,230.00$ & 383.60 \\
\hline & Total & 183.70 & 21.80 & 210.50 & 136.90 & 65.80 & 25.00 & 390.40 & 119.70 & $2,648.50$ & $5,918.00$ & 595.20 \\
\hline \multirow{5}{*}{ E. saligna } & Leaves & 66.50 & 4.00 & 26.70 & 14.90 & 10.00 & 4.00 & 92.50 & 17.60 & 248.40 & 574.90 & 38.60 \\
\hline & Branches & 8.70 & 1.60 & 17.60 & 31.30 & 10.80 & 1.90 & 39.80 & 36.60 & 221.60 & 594.70 & 46.40 \\
\hline & Stembark & 17.00 & 4.20 & 33.10 & 72.10 & 29.50 & 2.60 & 89.20 & 29.50 & 255.20 & $1,882.40$ & 57.50 \\
\hline & Stemwood & 53.60 & 5.90 & 95.70 & 34.50 & 25.90 & 15.10 & 131.20 & 80.00 & $1,993.90$ & 466.70 & 309.80 \\
\hline & Total & 145.70 & 15.70 & 173.10 & 152.80 & 76.10 & 23.70 & 352.80 & 163.80 & $2,719.10$ & $3,518.70$ & 452.30 \\
\hline \multirow{5}{*}{ E. dunnii } & Leaves & 66.00 & 3.80 & 18.50 & 19.90 & 10.80 & 3.90 & 59.50 & 19.50 & 309.90 & 941.40 & 46.70 \\
\hline & Branches & 8.20 & 1.10 & 10.90 & 19.30 & 8.10 & 1.40 & 29.30 & 20.40 & 217.20 & 791.90 & 34.80 \\
\hline & Stembark & 24.50 & 2.50 & 34.70 & 55.30 & 19.40 & 1.50 & 77.50 & 18.30 & 193.50 & $1,818.30$ & 57.00 \\
\hline & Stemwood & 41.50 & 4.80 & 74.10 & 38.20 & 30.30 & 10.40 & 150.40 & 51.00 & $1,304.20$ & $1,070.80$ & 155.20 \\
\hline & Total & 140.30 & 12.20 & 138.20 & 132.70 & 68.60 & 17.10 & 316.70 & 109.20 & $2,024.80$ & $4,622.30$ & 293.70 \\
\hline \multirow{5}{*}{$\begin{array}{l}\text { E. urophylla } \mathrm{x} \\
\text { E. globulus }\end{array}$} & Leaves & 120.00 & 6.40 & 40.80 & 27.30 & 14.00 & 6.60 & 99.40 & 27.60 & 548.80 & 1.457 .60 & 67.80 \\
\hline & Branches & 11.40 & 1.40 & 25.40 & 28.20 & 7.40 & 1.90 & 46.80 & 23.50 & 349.40 & 729.80 & 55.40 \\
\hline & Stembark & 17.90 & 2.80 & 43.50 & 51.90 & 19.70 & 2.40 & 95.40 & 18.40 & 198.00 & $1,556.70$ & 59.20 \\
\hline & Stemwood & 88.10 & 7.70 & 154.80 & 42.80 & 17.50 & 22.10 & 125.80 & 103.20 & $6,782.90$ & $1,018.30$ & 328.50 \\
\hline & Total & 237.40 & 18.40 & 264.50 & 150.20 & 58.70 & 33.00 & 367.40 & 172.70 & $7,879.00$ & $4,762.30$ & 511.00 \\
\hline \multirow{5}{*}{$\begin{array}{l}\text { E. urophylla } \mathrm{x} \\
\text { E. grandis }\end{array}$} & Leaves & 64.30 & 3.70 & 23.40 & 16.30 & 12.10 & 3.90 & 93.60 & 19.80 & 227.10 & 599.40 & 39.10 \\
\hline & Branches & 6.00 & 1.70 & 23.20 & 37.70 & 13.80 & 1.90 & 36.10 & 33.90 & 359.20 & $1,279.60$ & 63.30 \\
\hline & Stembark & 14.80 & 4.60 & 34.30 & 72.40 & 26.10 & 2.70 & 65.90 & 25.00 & 438.90 & $2,206.10$ & 53.40 \\
\hline & Stemwood & 73.00 & 7.30 & 143.00 & 46.10 & 22.90 & 14.80 & 259.50 & 122.50 & $2,553.30$ & 852.30 & 396.40 \\
\hline & Total & 158.00 & 17.20 & 223.90 & 172.50 & 74.90 & 23.40 & 455.00 & 201.10 & $3,578.50$ & $4,937.40$ & 552.10 \\
\hline
\end{tabular}

Source: Santos et al. (2019).

$\mathrm{N}$ was the element removed in greater quantity, the other scenarios and genotypes showed the highest export of the macronutrient $\mathrm{K}$. In the case of micronutrients, Fe was the element removed in greater quantity in the first scenario (harvesting of only stemwood). In the second (harvesting of stemwood and stembark) and third (harvesting of stem and canopy) scenarios, Mn was the micronutrient exported in greater quantity in all Eucalyptus species, except for E. uroglobulus, where the element removed in greater quantity was Fe. In contrast, the smallest exported micronutrient in all scenarios and genetic materials was $\mathrm{Cu}$.

It is worth mentioning that in the first scenario, the highest amount of nutrients exported with biomass harvesting occurred in E. urophylla $\mathrm{x}$ E. globulus $(\mathrm{N}, \mathrm{K}, \mathrm{S}$, and $\mathrm{Fe})$ and $E$. urophylla $\mathrm{x}$ E. grandis $(\mathrm{Ca}$, $\mathrm{B}, \mathrm{Cu}$, and $\mathrm{Zn}$ ). In the second scenario, the highest nutrient removal occurred in E. benthamii $(\mathrm{P} 1)(\mathrm{N}$, $\mathrm{P}, \mathrm{Ca}, \mathrm{Mn}$, and B) and E. urophylla $\mathrm{x}$ E. globulus 
Table 3. Nutrient export estimates for the three proposed harvest scenarios.

\begin{tabular}{|c|c|c|c|c|c|c|c|c|c|c|c|c|}
\hline \multirow{2}{*}{ Genotypes } & \multirow{2}{*}{ Intensidade } & $\mathrm{N}$ & $\mathrm{P}$ & K & $\mathrm{Ca}$ & $\mathrm{Mg}$ & $S$ & B & $\mathrm{Cu}$ & $\mathrm{Fe}$ & $\mathrm{Mn}$ & $\mathrm{Zn}$ \\
\hline & & \multicolumn{6}{|c|}{$\mathrm{kg} \mathrm{ha}^{-1}$} & \multicolumn{5}{|c|}{$\mathrm{g} \mathrm{ha}^{-1}$} \\
\hline \multirow{3}{*}{$\begin{array}{l}\text { E. benthamii } \\
\text { (P1) }\end{array}$} & $1^{*}$ & 65.47 & 12.30 & 143.54 & 41.94 & 20.10 & 13.25 & 210.31 & 78.28 & $4,956.14$ & $1,515.88$ & 360.86 \\
\hline & 2 & 109.60 & 17.10 & 192.20 & 171.70 & 50.30 & 15.90 & 325.60 & 104.40 & $5,221.40$ & $5,680.60$ & 491.60 \\
\hline & 3 & 222.70 & 25.56 & 251.61 & 237.58 & 75.51 & 24.02 & 455.19 & 152.16 & $6,170.60$ & $9,887.51$ & 638.16 \\
\hline \multirow{3}{*}{$\begin{array}{l}\text { E. benthamii } \\
\text { (P2) }\end{array}$} & 1 & 37.89 & 9.60 & 127.56 & 31.37 & 16.65 & 15.53 & 155.16 & 61.36 & $1,688.94$ & $1,229.97$ & 383.57 \\
\hline & 2 & 83.48 & 15.57 & 169.90 & 101.73 & 48.42 & 18.49 & 268.36 & 83.21 & $1,929.48$ & $3,682.31$ & 496.92 \\
\hline & 3 & 183.73 & 21.84 & 210.53 & 136.86 & 65.79 & 24.95 & 390.39 & 119.75 & $2,648.48$ & $5,917.96$ & 595.17 \\
\hline \multirow{3}{*}{ E. saligna } & 1 & 53.59 & 5.85 & 95.71 & 34.47 & 25.87 & 15.08 & 131.21 & 80.03 & $1,993.89$ & 466.66 & 309.77 \\
\hline & 2 & 70.60 & 10.00 & 128.80 & 106.60 & 55.30 & 17.70 & 220.50 & 109.60 & $2,249.10$ & $2,349.10$ & 367.30 \\
\hline & 3 & 145.74 & 15.69 & 173.14 & 152.78 & 76.13 & 23.66 & 352.77 & 163.83 & $2,719.08$ & $3,518.72$ & 452.26 \\
\hline \multirow{3}{*}{ E. dunnii } & 1 & 41.51 & 4.78 & 74.08 & 38.20 & 30.26 & 10.36 & 150.38 & 51.04 & $1,304.24$ & $1,070.80$ & 155.23 \\
\hline & 2 & 66.00 & 7.30 & 108.80 & 93.50 & 49.60 & 11.90 & 227.90 & 69.30 & $1,497.70$ & $2,889.10$ & 212.20 \\
\hline & 3 & 140.28 & 12.24 & 138.23 & 132.67 & 68.59 & 17.12 & 316.73 & 109.24 & $2,024.84$ & $4,622.35$ & 293.70 \\
\hline \multirow{3}{*}{$\begin{array}{l}\text { E. urogphylla } \\
\mathrm{x} \\
\text { E. globulus }\end{array}$} & 1 & 88.07 & 7.68 & 154.82 & 42.76 & 17.55 & 22.13 & 125.75 & 103.17 & $6,782.85$ & $1,018.28$ & 328.53 \\
\hline & 2 & 105.98 & 10.52 & 198.30 & 94.70 & 37.28 & 24.50 & 221.20 & 121.60 & $6,980.84$ & $2,574.95$ & 387.77 \\
\hline & 3 & 237.39 & 18.36 & 264.46 & 150.18 & 58.71 & 33.02 & 367.39 & 172.71 & $7,879.01$ & $4,762.32$ & 511.04 \\
\hline \multirow{3}{*}{$\begin{array}{l}\text { E. urogphylla } \\
\text { x E. grandis }\end{array}$} & 1 & 72.98 & 7.28 & 143.01 & 46.15 & 22.93 & 14.84 & 259.47 & 122.46 & $2,553.26$ & 852.34 & 396.35 \\
\hline & 2 & 81.65 & 11.86 & 167.09 & 121.32 & 50.45 & 16.98 & 322.06 & 141.04 & $2,973.02$ & $3,225.62$ & 448.77 \\
\hline & 3 & 151.93 & 17.21 & 213.70 & 175.29 & 76.33 & 22.86 & 451.77 & 194.75 & $3,559.35$ & $5,104.62$ & 551.15 \\
\hline
\end{tabular}

$1^{*}$ - Harvesting the stemwood; 2 - Harvesting the stemwood with stembark; 3 - Harvesting of all aboveground biomass.

$(\mathrm{K}, \mathrm{S}$, and $\mathrm{Fe})$. In the third scenario, the highest nutrient exportation occurred in E. benthamii (P1) (P, Ca, B, Mn, and Zn), E. urophylla $\mathrm{x}$ E. globulus $(\mathrm{N}, \mathrm{K}, \mathrm{S}$, and $\mathrm{Fe})$, and $E$. grandis $(\mathrm{Mg}$ and $\mathrm{Cu})$. In contrast, E. dunnii (P, K, S, Cu, Fe, and $\mathrm{Zn}$ ) and E. benthamii $(\mathrm{P} 2)(\mathrm{N}, \mathrm{Ca}$, and $\mathrm{Mg})$ had the lowest amounts of nutrients exported. In the second scenario, E. dunnii showed the lowest amounts of nutrients (N, P, Ca, S, Cu, Fe, and $\mathrm{Zn}$ ) removed. The potential export of nutrients from Eucalyptus stands harvested may be high. However, depending on the harvest method, the nutrients from the residue can be recycled (Hernández et al., 2009). According to Merino et al. (2005), the cost of harvesting in terms of nutrients can also be reduced by carefully selecting the planted tree species and their parts for harvesting and by reducing the intensity of the harvest.

When the wood is harvested with the bark, the export of nutrients is increased considerably, reaching $63 \%$ and $74 \%$ of $\mathrm{Ca}$ and $64 \%$ and $74 \%$ of $\mathrm{Mg}$ removed from E. uroglobulus and E. benthamii (P2), respectively. According to Viera et al. (2015), the availability of nutrients for future plantations in a forest site is mainly related to the harvest intensity applied. In this perspective, for the greater sustainability of forest stands, the debarking of trees should be carried out before removing their trunks; this would be an effective way to reduce nutrient export. This is because without proper silvicultural management, intensive harvesting might lead to the depletion of nutrient stocks in soils in the long term (Merino et al. 2005).

According to Witschoreck (2008), a part of the nutrients extracted by forest harvesting can be replenished through the application of fertilizers. However, in addition to the economic and ecological aspects of the use of fertilizers, it is difficult to quantify and assess the quality of nutrients, restricting fertilizer application, in most cases, to the triad of NPK elements.

It should be noted that forest harvesting, from the nutritional point of view, should not be carried out in many young stands because of the higher export of nutrients per unit of biomass produced. Besides, for the next rotation, sustainable production practices 
should be carried out to maintain the nutritional balance of the site of harvest (Viera et al. 2015).

\section{Conclusions}

Harvesting of all aboveground biomass was the most aggressive scenario showing the highest export of nutrients.
However, for reducing the nutritional impact of biomass harvesting, the best scenario was the one in which only stemwood was harvested.

\section{Acknowledgements}

\author{
The company Celulose Riograndense \\ - CMPC
}

\section{Literature Cited}

Alvares, C.A.; Stape, J.L.; Sentelhas, P.C.; Gonçalves, J.L.M.; Sparovek, G.

2013. Köppen's climate classification map for Brazil. Meteorologische Zeitschrift, 22 (6): 1-18.

Bellote, A.F.J.; Silva, H.D.

2004. Sampling techniques and nutritional evaluations in eucalypt plantations, In: Gonçalves J.L.M.; Benedetti V. Forest nutrition and fertilization. IPEF. Piracicaba, Brazil. p. 113-139.

Bellote, A.F.J.; Dedecek, R.A.; Silva, H.D.

2008. Nutrientes minerais, biomassa e deposição de serapilheira em plantio de Eucalyptus com diferentes sistemas de manejo de resíduos florestais. Pesquisa Florestal Brasileira, 56: 31-41.

Drumond, M.A.; Barros, N.F.; Souza, A.L.; Silva, A.F.

1997. Distribuição de biomassa e de nutrientes em diferentes coberturas florestais e pastagem na região do Médio Rio Doce-MG. Revista Árvore, 21(2): 187-1997.

EMBRAPA.

2009. Centro Nacional de Pesquisa de Solos (Rio de Janeiro, RJ). Sistema brasileiro de classificação de solos. EMBRAPA-SPI. Rio de Janeiro, Brazil. 412 p.

Gonçalves, J.L.M.; Alvares, C.A.; Higa, A.R.; Silva, L.D.; Alfenas, A.C.; Stahl, J.; Ferraz, S.B.; Lima, W.P.; Brancalion, P.H.S.; Hubner, A.; Bouillet, J.P.D.; Laclau, J.P.; Nouvellon, Y.; Epron, D. 2013. Integrating genetic and silvicultural strategies to minimize abiotic and biotic constraints in Brazilian eucalypt plantations. Forest Ecology and Management, 301: 6-27.

Hernández, J.; Del Pino, A.; Salvo, L.; Arrarte, G.

2009. Nutrient export and harvest residue decomposition patterns of a Eucalyptus dunnii Maiden plantation in temperate climate of Uruguay. Forest Ecology and Management, 258(2): 92-99.

Londero, E.K.; Schumacher, M.V.; Szymcza, D.A.; Viera, M. 2001. Exportação e reposição nutricional no primeiro desbaste de um povoamento de Pinus taeda L. em área de segunda rotação. Ciência Florestal, 21: 487-497.
Merino A.; Balboa, M.A.; Rodríguez Soalheiro, R.; Álvarez González, J.G.

2005. Nutrient exports under different harvesting regimes in fast-growing forest plantations in southern Europe. Forest Ecology and Management, 207: 325-339.

Mora, A.L.; Garcia, C.H.

2000. A cultura do eucalipto no Brasil. Sociedade Brasileira de Silvicultura. São Paulo, Brazil. 112 p.

Santana, R.C.; Barros, N.F.; Novais, R.F.; Leite, G.L.; Comerford, N.B.

2008. Alocação de nutrientes em plantios de eucalipto no Brasil. Revista Brasileira de Ciência do Solo, 32: 2723-2733.

Santos, K.F.; Schumacher, M.V.; Ludvichak, A.A.; Araújo, E.F. 2019. Biomass and stock of nutrients in different genotypes of eucalypts in Southern Brazil. Journal of Experimental Agriculture International, 34(4): 1-12.

Silva, H.D.; Poggiani F.; Coelho, L.C.

1983. Biomassa, concentração e conteúdo de nutrientes em cinco espécies de Eucalyptus plantadas em solos de baixa fertilidade. Boletim de Pesquisa Florestal, (6/7): 9-25.

Viera, M.; Schumacher, M.V.; Caldeira, M.V.W.

2015. Biomassa e exportação de nutrientes pela colheita do eucalipto. In: Schumacher M.V.; Viera M. Silvicultura do Eucalipto no Brasil. Editora UFSM. Santa Maria, Brazil. pp. 245-272.

Wang, H.; Xueyun, D.; Yajuan, X.; Zhengquan, W.; Guoyong,

Y.; Jianyu, W.; Qinggui W.

2016. Nutrient exports under different harvesting regimes in two types of larch plantation with different age in Northeastern China. Journal of Energy and Natural Resources, 5: 67-77.

Witschoreck, R.

2008. Biomassa e nutrientes no corte raso de um povoamento de Pinus taeda L. de 17 anos de idade no município de Cambará do Sul - RS. Universidade Federal de Santa Maria. Santa Maria, Brazil. 81 p. 